\title{
Peran BPOM dalam Melakukan Pengawasan terhadap Pangan Tanpa Izin Edar
}

\author{
Tresya ${ }^{1}$ \\ Fakultas Hukum Universitas Batanghari \\ Jl. Slamet Riyadi Brorni Kota Jambi (0741) 65351
}

\begin{abstract}
Abstrak
Pangan merupakan kebutuhan dasar sebagai hak setiap manusia dan sebagai salah satu faktor penentu kualitas sumber daya manusia. Ketidakseimbangan gizi akibat konsumsi pangan yang tidak terjamin berdampak pada kesehatan masyarakat selaku konsumen. Penelitian ini bertujuan untuk mengetahui dan menganalisis keamanan pangandan peran BPOM sebagai pihak yang membantu dalam pengawasan terhadap keamanan pangan. Metode yang digunakan adalah pendekatan dalam metode pendekatan ini, penulis melakukan pendekatan yuridis empiris, yaitu penelitian yang dilakukan terhadap fakta hukum yang ada dengan melakukan penelitian secara langsung ke lapangan untuk mengetaui pelaksanaan dan masalah-masalah yang timbul.
\end{abstract}

Kata Kunci : Keamanan Pangan, Peran BPOM, Pengawasan

\begin{abstract}
Food is a basic need as the right of every human being and as one of the determinants of the quality of human resources. Nutritional imbalances due to unsure food consumption have an impact on public health as consumers. This study aims to find out and analyze the security of the food and the role of the BPOM as a party that assists in monitoring food security. The method used is an approach in this approach method, the author employs an empirical juridical approach, namely research conducted on existing legal facts by conducting research directly into the field to determine the implementation and problems that arise.
\end{abstract}

Keywords: Food Safety, Role of BPOM, Supervision

\section{PENDAHULUAN}

Pangan memegang peranan penting dalam upaya peningkatan kualitas sumber daya manusia. Oleh karena itu, pemenuhan penyediaan pangan juga tergolong sebagai hak asasi manusia. Kemampuan menyediakan pangan bagi rakyat merupakan indikator kemajuan suatu bangsa. ${ }^{2}$

Keamanan pangan (food safety) merupakan hal-hal yang membuat makanan itu aman untuk dimakan, bebas dari faktor-faktor penyebab penyakit misalnya banyak mengandung sumber penular penyakit (infactius agent), mengandung bahan kimia beracun, dan mengandung benda asing (foreign objects).

Kesadaran konsumen pada pangan adalah memberikan perhatian terhadap nilai gizi dan keamanan pangan yang dikonsumsi. Faktor keamanan pangan berkaitan dengan tercemar tidaknya pangan oleh cemaran mikro biologis, logam berat, dan bahan kimia yang membahayakan kesehatan. Untuk dapat memproduksi pangan yang bermutu baik dan aman bagi kesehatan, tidak cukup hanya mengandalkan pengujian akhir di laboratorium saja, tetapi juga diperlukan adanya penerapan sistem jaminan mutu dan sistem manajemen lingkungan, atau penerapan sistem produksi pangan yang baik (GMP- Good Manufacturing Practices) dan penerapan analisis bahaya dan titik kendali kritis (HACCP- Hazard Analysis and Critical Control Point). ${ }^{3}$

Pangan yang bermutu dan aman dapat dihasilkan dari dapur rumah tangga maupun industri pangan. Dapat dikatakan bahwa industri pangan merupakan salah satu faktor penentu beredarnya pangan yang memenuhi standar mutu dan keamanan yang telah ditetapakan oleh pemerintah. Pemerintah juga telah melakukan sederetan usaha atau langkah pengendalian kontaminan pangan melalui inspeksi, registrasi, analisa produk akhir untuk menentukan apakah produk yang dihasilkan oleh suatu industri pangan merupakan produk yang aman dikonsumsi. Untuk melindungi masyarakat dari produk pangan olahan yang berbahaya, pemerintah telah mengeluarkan peraturan perundang-undangan yang berkaitan dengan masalah

\footnotetext{
1 Tresya, SH, MH,. Dosen Tetap PS Ilmu Hukum Fakultas Hukum Universitas Batanghari Jambi

2 Hafzah, Kedaulatan Pangan, Pustaka Sinar Harapan, 2006, hlm 13.

${ }^{3}$ https://delfistefani.wordpress.com/2013/12/15/makalah-ketahanan-pangan/ diakses pada tanggal 18 Oktober 2018
} 
keamanan pangan. Instansi pemerintah yang bertugas dan bertanggung jawab terhadap peredaran produk pangan olahan diseluruh Indonesia adalah Badan Pengawasan Obat dan Makanan (BPOM). Penemuan makanan yang kadaluarsa dan tidak memiliki izin edar cenderung meningkat pada bulan puasa dan hari raya. Peningkatan itu mencapai dua kali lipat.

Berdasarkan latar belakang yang diuraikan diatas maka rumusan masalah dalam penelitian adalah bagaimana peran Badan Pengawasan Obat dan Makanan terhadap pangan tanpa izin edar dan mengandung bahan berbahaya?

Berdasarkan latar belakang dan persoalan penulisan yang telah dirumuskan, penulisan ini bertujuan untuk mengetahui peran Badan Pengawasan Obat dan Makanan terhadap pangan tanpa izin edar dan mengandung bahan berbahaya di Kota Jambi.

Hasil penelitian ini diharapkan dapat bermanfaat bagi perusahaan yang memproduksi berbagai jenis makanan sebagai bahan informasi dan referensi, sehingga bias sebagai bahan pertimbangan dalam merancang strategi untuk pengembangan produk yang sehat dan aman dikonsumsi oleh masyarakat.

Bagi penulis merupakan sarana pengembangan wawasan serta pengalaman dalam menganalisis permasalahan khususnya di kemanan pangan dan peran BPOM, dan bagi kalangan akademisi dapat dijadikan bahan penyusunan penelitian yang serupa dan lebih mendalam.

\section{METODE PENELITIAN}

Dalam metode pendekatan ini, penulis melakukan pendekatan yuridis normatif. Penelitian hukum normatif meletakkan hukum sebagai sistem norma. Sistem norma adalah asas-asas, norma, kaidah dari peraturan perundang-undangan, putusan pengadilan, perjanjian serta doktrin (ajaran). ${ }^{4}$ Tipe penelitian ini dilakukan dengan menganalisis ketentuan peraturan-peraturan hukum yang berkaitan dengan Badan Pengawasan Obat dan Makanan (BPOM) yaitu Undang-Undang Nomor 8 Tahun 1999 Tentang Perlindungan Konsumen.

Bahan hukum yang dikaji dan di analisis dalam penelitian hukum normatif terdiri dari bahan hukum primer adalah semua aturan tertulis yang ditegakkan oleh negara, semua itu bisa ditemukan dalam putusan pengadilan yang telah berkekuatan hukum tetap, undang-undang yang ditetapkan parlemen, keputusan dan peraturan eksekutif dan putusan agen-agen administrasi. ${ }^{5}$ Dengan demikian, bahan hukum primer meliputi pembukaan Undang-Undang Dasar 1945, peraturan dasar yaitu batang tubuh Undang-Undang Dasar 1945, peraturan perundang-undangan, bahan hukum yang tidak dikodifikasi seperti hukum adat, yurisprudensi, traktat dan bahan hukum yang merupakan warisan penjajahan seperti KUHP, bahan hukum sekunder. Dalam penelitian ini bahan hukum sekunder yang digunakan adalah buku-buku hukum, artikel-artikel tentang hukum, kamus hukum atau ensiklopedia hukum dan koran atau majalah yang berkaitan dengan penelitian proposal skripsi ini dan bahan hukum tersier adalah bahan hukum yang memberikan penjelasan mengenai bahan hukum primer dan bahan hukum sekunder. ${ }^{6}$ Situs-situs internet memiliki peranan penting dalam upaya mencari bahan-bahan hukum. ${ }^{7}$

Teknik untuk mengkaji dan mengumpulkan ketiga bahan hukum tersebut dengan menggunakan studi dokumenter. Studi dokumenter merupakan studi yang mengkaji tentang berbagai dokumen-dokumen, baik yang berkaitan dengan peraturan perundang-undangan maupun dokumen-dokumen yang sudah ada. ${ }^{8}$

Teknik analisis dalam penelitian ini adalah analisis kualitatif. Analisis kualitatif merupakan analisis data yang tidak menggunakan angka, melainkan memberikan gambaran-gambaran (deskripsi) dengan katakata atas temuan-temuan dan karenanya ia lebih mengutamakan mutu/kualitas dari data dan bukan kuantitas. $^{9}$

${ }^{4}$ H. Salim Hs Dan Erlies Septiana Nurbani, Penerapan Teori Hukum Pada Penelitian Tesis Dan Disertasi, PT. Raja Grafindo Persada, Jakarta, 2013, hlm 13.

${ }^{5}$ I Made Pasek Diantha, Metodologi Penelitian Hukum Normatif Dalam Justifikasi Teori Hukum, Kencana, Jakarta, 2016, hlm 13.

${ }^{6}$ H. Salim Hs Dan Erlies Septiana Nurbani, Op.Cit, hlm 16.

7 I Made Pasek Diantha, Op.Cit, hlm 147.

8 Ibid.

9 Ibid. 


\section{HASIL DAN PEMBAHASAN}

Pentingnya optimalisasi peran bersama antara Badan Pengawasan Obat dan Makanan (BPOM) dengan berbagai lembaga terkait untuk melakukan pengawasan terhadap produk makanan kadaluarsa, produk berformalin dan berkeqamasan rusak terutama pada saat menjelang Ramadhan dan lebaran. Lembaga terkait ini mempuyai peran yang strategis dalam penanggulangan makanan dan obat-obatan yang kadaluarsa, berformalin dan berkemasan rusak, misalnya dilibatkannya lembaga Kepolisian dan Dinas Perindustrian dan Perdagangan (Disperindag) yang tersebar Kabupaten/Kota Provinsi guna untuk melakukan penyitaan dan pencabutan izin usaha apabila ketentuan keamanan mengenai pengan dilanggar. Operasi pasar secara sebagai salah satu upaya untuk meminimalisir penyimpangan dan tindak pidana yang dilakukan dalam perdagangan. Upaya ini tentu sangat berpengaruh terhadap intensitas peredaran produk makanan yang bermasalah.

Badan Pengawasan Obat dan Makanan (BPOM) harus senantiasa mengembangkan pemantauan dan pengawasan terhadap makanan dan obat-obatan yang beredar luas di masyarakat. Pencegahan sejak dini harus dilakukan agar tidak ada korban. Program-program Badan Pengawasan Obat dan Makanan (BPOM) juga harus berintegrasi agar hasilnya juga maksimal. Sebagai lembaga yang berwenang dalam melakukan pengawasan obat dan makanan Badan Pengawasan Obat dan Makanan (BPOM) diharapkan memiliki kebijakan strategis dan tindakan kongkrit yang langsung menyentuh ke masyarakat. Permasalahan makanan kadaluwarsa bukan hanya menjadi isu kelas menengah ke atas, namun hampir menyentuh seluruh lapisan masyarakat, dan tak jarang, masyarakat yang menengah ke bawah lah yang sering menjadi korban.

Kewenangan terbesar penertiban makanan bermasalah ada di Badan Pengawasan Obat dan Makanan (BPOM), disamping lembaga lain yang juga berwenang. Untuk itu diharapkan Badan Pengawasan Obat dan Makanan (BPOM) mengambil inisiatif untuk koordinasi dengan instansi lain, meskipun harus diakui terkadang ada kendala teknis pengawasan terkait tugas pokok dan fungsi masing-masing instansi. Begitupun lanjutnya, dalam situasi frekuensi transaksi kebutuhan pokok begitu melonjak dan tingkat kehati-hatian masyarakat menurun, maka Badan Pengawasan Obat dan Makanan (BPOM) dan instansi lain perlu memperkuat koordinasi pengawasan.Bagaimanapun masih adanya dugaan makanan kadaluarsa di pasaran atau pusat perbelanjaan perlu perhatian serius dari pemerintah. Artinya jangan sampai masyarakat dirugikan.

Untuk mengatasi maraknya peredaran makanan yang kadaluarsa, berformalin dan berkemasan rusak, Undang-Undang Nomor 36 Tahun 2009 tentang Kesehatan dalam Pasal 111 ayat (1) menyatakan bahwa "makanan dan minuman yang digunakan masyarakat harus didasarkan pada standar dan/atau persyaratan kesehatan".

Terkait hal tersebut di atas, Undang-Undang tersebut menjelaskan bahwa makanan dan minuman yang tidak memenuhi ketentuan standar, persyaratan kesehatan, dan/atau membahayakan kesehatan dilarang untuk diedarkan, ditarik dari peredaran, dicabut izin edar dan disita untuk dimusnahkan sesuai dengan ketentuan peraturan perundang-undangan. Untuk itu kita berharap semoga Badan Pengawasan Obat dan Makanan (BPOM) dapat melakukan penertiban terhadap produk makanan yang ditenggarai bermasalah dan berpotensi menimbulkan korban jiwa.

Tugas Utama BPOM berdasarkan Pasal 67 Keputusan Presiden Nomor 103 Tahun 2001, BPOM melaksanakan tugas pemerintahan di bidang pengawasan Obat dan Makanan sesuai dengan ketentuan peraturan perundang-undangan yang berlaku. ${ }^{10}$

Peraturan Pemerintah Nomor 38 Tahun 2007 tentang Pembagian Urusan Pemerintahan Antara Pemerintah, Pemerintah Daerah Provinsi, dan Pemerintah Daerah Kabupaten/Kota pada Bidang Kesehatan sub bidang Obat dan Perbekalan Kesehatan, mengamanatkan bahwa "pengawasan dan registrasi makanan minuman produksi rumah tangga merupakan urusan pemerintahan yang wajib diselenggarakan oleh Pemerintah Daerah Kabupaten/Kota".

Tanggung jawab ini tentunya dapat dilaksanakan dengan sebaik mungkin, tanpa mengorbankan salah satu pihak (pihak konsumen dan pelaku usaha).

Dalam penjelasan Undang-Undang Nomor 8 Tahun 1999 Tentang Perlindungan Konsumen, disebutkan bahwa faktor utama yang menjadi kelemahan konsumen adalah tingkat kesadaran konsumen akan haknya masih rendah. Hal ini terutama disebabkan oleh rendahnya pendidikan konsumen. Oleh karena

\footnotetext{
${ }^{10}$ Makmur, Efektifitas Kebijakan Kelembagaan Pengawasan, PT. Refika Aitama, Bandung, 2011, hlm 73.
} 
itu, Undang-Undang Perlindungan Konsumen dimaksudkan menjadi landasan hukum yang kuat bagi pemerintah dan lembaga perlindungan konsumen swadaya masyarakat unluk melakukan upaya pemberdayaan konsumen melalui pembinaan dan pendidikan konsumen.

Mengenai sanksi pidana dalam Undang-undang ini dapat dilihat dalam Pasal 62 mengenai pelaku usaha dan/atau pengurus yang melakukan tindak pidana, dengan pidana denda paling banyak sebesar 500 juta rupiah dan pidana penjara paling lama 5 (lima) tahun serta sanksi administratif berupa ganti rugi paling banyak 200 juta rupiah.

Terhadap sanksi pidana sebagaimana dimaksud dalam Pasal 62, dapat dijatuhkan hukuman tambahan yang diatur dalam Pasal 63, berupa:

a) perampasan barang tertentu;

b) pengumuman keputusan hakim;

c) pembayaran ganti rugi;

d) perintah penghentian kegiatan tertentu yang menyebabkan timbulnya kerugian konsumen;

e) kewajiban penarikan barang dari peredaran;

f) pencabutan izin usaha.

Untuk itu perlu diterapkan sanksi hukum pidana dan administrasi kepada mereka yang sengaja mengedarkan dan menjual produk makanan bermasalah.

Sekecil apapun sanksi yang diberikan tetap penting ditegakkan agar masyarakat lebih aman dan nyaman menjalani puasa dan lebaran. Intinya, perlu adanya pengawasan pangan terhadap pangan kedaluarsa, pangan ilegal, label, pangan rusak, dan lain-lain termasuk pengawasan penggunaan bahan berbahaya dalam pangan. Badan Pengawasan Obat dan Makanan (BPOM) dalam hal ini dapat memberikan informasi yang dibutuhkan masyarakat serta pengawasan yang berkelanjutan kedepannya.

Menyikapi kondisi saat ini maka konsumen harus jeli dan hati-hati dalam berbelanja. Misalnya menyangkut keamanan pangan yang mempunyai efek samping (side effect) sangat berbahaya dan merugikan masyarakat apabila keamanan pangan tidak dikontrol (manajemen kontrol) yang baik. Untuk itu maka Badan Pengawasan Obat dan Makanan (BPOM) bersama lembaga terkait harus diusahakan maksimal sehingga keselamatan dan kesehatan konsumen dapat terjamin. Semoga saja Badan Pengawasan Obat dan Makanan (BPOM) dan lembaga terkait lainnya dapat berkerja professional demi tercapainya keamanan pangan yang layak konsumsi.

\section{SIMPULAN}

Kerjasama dibutuhkan dari pihak BPOM dan konsumen, konsumen harus selektif dan hati-hati memilih dan memilah, mana makanan yang sehat dikonsumsi dan mana makan yang kurang sehat atau bahkan berbahaya bagi kesehatan. Pihak produsen jaga harus ikut serta menjaga kesehatan konsumen, berhati-hati dalam memproduksi makanan olahannya, harus memilih bahan-bahan yang tidak berbahaya bagi kesehatan, harus mematuhi aturan-aturan yang berlaku, jangan hanya mementingkan kepentingannya sehingga kepentingan konsumen diabaikan. Barang yang tidak layak dijual harus dibuang atau disingkirkan dan tidak dijajakan.

\section{DAFTAR PUSTAKA}

\section{Buku}

Hafzah, Kedaulatan Pangan, Pustaka Sinar Harapan, 2006.

Makmur, Efektifitas Kebijakan Kelembagaan Pengawasan, PT. Refika Aitama, Bandung, 2011

\section{Peraturan Perundang-undangan}

Undang-Undang No. 8 Tahun 1999 Tentang Perlindungan Konsumen

Peraturan Pemerintah Nomor 38 Tahun 2007 tentang Pembagian Urusan Pemerintahan Antara Pemerintah, Pemerintah Daerah Provinsi, dan Pemerintah Daerah Kabupaten/Kota pada Bidang Kesehatan - sub bidang Obat dan Perbekalan Kesehatan

Undang-Undang Nomor 36 Tahun 2009 tentang Kesehatan 
Peran BPOM dalam Melakukan Pengawasan terhadap Pangan Tanpa Izin Edar

\section{Internet}

https://delfistefani.wordpress.com/2013/12/15/makalah-ketahanan-pangan/diakses pada tanggal 18 Oktober 2018 